\title{
ANTIHYPOXIC ACTIVITY OF PYRIMIDINE DERIVATIVE PIR-9 IN HYPOBARIC HYPOXIA IN MICE
}

\section{Andrey Voronkov ${ }^{1}$ (D), Natalia Shabanova ${ }^{1 凶}$ (D), Maria Voronkova ${ }^{2}$, Tatiana Lysenko ${ }^{1}$, Arkady Arlt' ${ }^{1}$, Elena Zatsepina ${ }^{7}$}

1'Pyatigorsk Medical and Pharmaceutical Institute - Branch of Volgograd State Medical University, Pyatigorsk, Russia

${ }^{2}$ The Volgograd State Medical University, Volgograd, Russia

\section{$\triangle$ Vahlushina@mail.ru}

ABSTRACT - A study was conducted to assess the effect of a new pyrimidine derivative (PIR-9 $50 \mathrm{mg} / \mathrm{kg}$ ) on the resistance of mice to acute hypobaric hypoxia. It was confirmed that the studied compound PIR- 9 contributes to an increase in the life time at the test site by 2,07 times $(p<0.05)$ compared to the control group of animals and exceeds the strength of the effect of the reference drug Mexidol by $15,38 \%(p<0,05)$.

KEYW ORDS - cerebral circulation, hypobaric hypoxia, pyrimidine derivatives, Mexidol.

\section{INTRODUCTION}

In the pathogenesis of almost all types of cerebrovascular disorders, hypoxia and its induced processes are an integral part of pathobiochemical reactions in conditions of oxygen deficiency [1]. The effectiveness of cerebroprotective agents is significantly affected by their ability to neutralize the consequences or mitigate the course of hypoxia [2]. Previously, the potential cerebroprotective activity of pyrimidine derivatives has been proved [3], and therefore it is interesting to study the antihypoxic effect of these derivatives as one of the possible mechanisms of anti-ischemic action.

\section{Objective}

To study the antihypoxic activity of pyrimidine derivative PIR-9 in hypobaric hypoxia in mice.

\section{MATERIALS AND METHODS}

The experiment was performed in accordance with the "Guidelines for preclinical studies of drugs, ed. A. N. Mironov (2012 Ed.) [4]. The study was conducted on 30 mongrel white mice $(\mathrm{m}=20-24 \mathrm{~g})$. The animals were divided into 3 groups $(n=10)$. The animals were kept in controlled vivarium conditions with natural light-dark regime change with free access to water and food. The first group - the control group, received a suspension of purified water with tween-80, the second group was administered the compound PIR-9 $(50 \mathrm{mg} / \mathrm{kg})$ [5], the third - the comparison drug Mexidol (50 mg/kg) [6,7]. All objects were injected intraperitoneal for an hour before the experiment. Acute hypobaric hypoxia was modeled by "lifting" mice in a hyperbaric chamber $(\mathrm{h}=11000 \mathrm{~m}$, $v=100 \mathrm{~m} / \mathrm{s}$ ) $[8,9]$. All findings were processed by means of variation statistics methods using the STATISTICA 6.0 software. The normality of distribution was assessed by the Shapiro-Wilk test. In the case of a normal distribution of the data, a parametric t-test was applied. In the case of abnormal distribution of the data, the statistical processing was performed using the Mann-Whitney U-test. The difference was considered significant at the significance level of more than $95 \%$ $(\mathrm{p}<0,05)$.

\section{RESULTS}

Testing for resistance of mice to acute hypobaric hypoxia showed that the average life expectancy of animals treated with intraperitoneal experimental substance PIR-9 was 104,3 $\pm 2,61$ seconds, which was 2,07 times $(p<0,05)$ was statistically significantly higher than that of the control group $(50,3 \pm 2,69 \mathrm{sec}-$ onds). The life time at the "death site" in mice, which were administered the comparison drug Mexidol, was $90,4 \pm 3,22$ seconds and $1,79(\mathrm{p}<0.05)$ times higher than the control group. At the same time, the life expectancy of PIR-9 animals exceeded the value of Mexidol group by $15,38 \%(\mathrm{p}<0,05)$, which was statistically significant.

\section{CONCLUSION}

The use of a new pyrimidine derivative under laboratory code the PIR-9 $(50 \mathrm{mg} / \mathrm{kg})$ significantly increased the life expectancy of mice by 2,07 times compared to the control group and by 1,79 times compared to mice treated with Mexidol, which may indicate the antihypoxic effect of this compound, exceeding the comparison drug Mexidol at a dose of 50 $\mathrm{mg} / \mathrm{kg}$. Since the antihypoxic effect can be one of the mechanisms of cerebroprotective activity, this pyrimidine derivative is a promising object for further study and correction of ischemic brain damage.

\section{REFERENCES:}

1. Evseeva M. A., Evseev, A.V., Pravdivtsev, V. A., Shabanov, P. D. Mechanisms of acute hypoxia and 
Fig. 1. Assessment of the effect of PIR-9 compound and Mexidol on the lifespan of mice in hypobaric hypoxia

Note: Control — control group of mice, Mexidol group of mice treated with Mexidol; PIR-9 — group of mice treated with PIR-9; \# — statistically significant relative to the control group of mice $(p<0,05) ;{ }^{*}$ - statistically significant relative to the group of mice treated with Mexidol $(p<0,05)$.

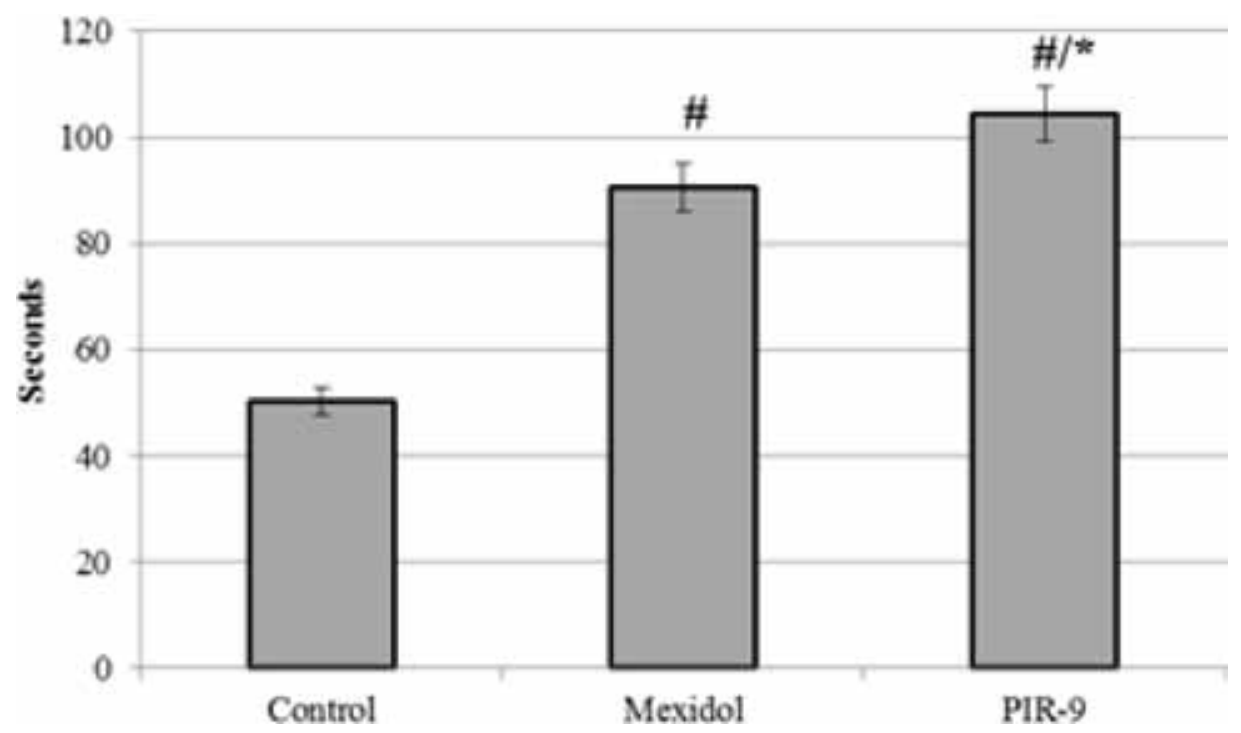

ways of its pharmacological correction / / Reviews of clinical pharmacology and drug therapy. - 2008. - Vol. 6. - №. 1 (In Russ.)

2. Kurkin D. V., Volotova E. V., Litvinov A. A., BAKulin D. A., Ozerov, A. A. Investigation of cerebroprotective and antihypoxic activity of $\gamma$-hydroxy and $\gamma$-aminobutyric acid derivatives / Siberian medical journal (Irkutsk). - 2012. - Vol. 111. - №. 4. P. 107-109. (In Russ.)

3. Voronkov A.V., Shabanova N.B., Kodonidi I.P., Shatalov I.S. Cerebroprotective activity of new derivatives of pirimidine-4-(1H)-one PIR-9 and PIR-10 in irreversible occlusion of the common carotid artery. Pharmacy \& Pharmacology. 2018;6(2):167-181. (In Russ.) DOI: 10.19163/2307-9266-2018-6-2-167-181

4. Mironov A.N. The guidelines for preclinical studies of pharmaceuticals. Part one. - M.: Grif and K, 2012. - 944 p. (In Russ.)

5. Voronkov A.V., Shabanova N.B., Voronkova M.P., LySENKo T.A. Study of cerebrotropic dosedependent effect of pyrimidine derivative under pir-9 code against the background of experimental cerebral ischemia in rats. Pharmacy \& Pharmacology. 2018;6(6):548-567. (In Russ.) DOI: 10.19163/23079266-2018-6-6-548-567

6. Katunin, N. P., Gneushev I. M., Parfenov E. A. Experimental study of the antihypoxic activity of new physiologically compatible antioxidants under the code $\pi$ qHa model of acute hypoxia with hypercapnia // Bulletin of Bryansk state University. - 2012. №. 4 (2). - P. 142-145. (In Russ.)

7. Inchina, V. I., Korshunova, A. B., Prosvirkina, I. A., Semenov, A.V., Ulanova, T. V., ChairKIN, I. N. Comparative evaluation of some effects of z-hydroxypyridine and pyrimidine derivatives in experiment //Bulletin of new medical technologies. 2010. - Vol. 17, - №. 3. - P. 158-160. (In Russ.)
8. Pogorelov E. V., Makarova, L. M., Novikova, N. A., \& Skacelova, S. Y. the Study of the effectiveness of a derivative of taurine in experimental a hypobarium //pharmacy and pharmacology. - 2015. - Vol. 3. - №. 5s. - P. 82-83. (In Russ.)

9. ODRINSKY P. N. Influence of Allim-2 on the life expectancy of mice in acute hypobaric hypoxia / / Nauka i sovremennost. - 2010. - №. 5-2. - P. 310-313. (In Russ.) 